\title{
PENGEMBANGAN DAN PEMANFAATAN PUPUK ORGANIK EKSTRAK TANAMAN PADA BUDIDAYA PERTANIAN ORGANIK DI LAMPUNG SELATAN
}

\author{
Darwin H. Pangaribuan ${ }^{1 *}$, F.X. Soesilo ${ }^{2}$, Joko Prasetyo \\ ${ }^{1}$ Jurusan Agronomi dan Hortikultura, Fakultas Pertanian, Universitas Lampung \\ ${ }^{2}$ Jurusan Hama Penyakit Tanaman, Fakultas Pertanian, Universitas Lampung \\ *Penulis Korespondensi: darwin.pangaribuan@fp.unila.ac.id
}

\begin{abstract}
Abstrak
Pertanian organik semakin populer di kalangan petani sebagai praktik pertanian alternatif. Kebutuhan unsur hara mayor dalam pertanian organik dapat dicukupi dari bahan alamiah yaitu dari bahan ekstrak tanaman. Organ tanaman kaya akan unsur hara misalnya ekstrak tanaman daun tanaman lamtoro kaya akan unsur Nitrogen, ekstrak batang pisang kaya akan unsur Fosfor, dan ekstrak sabut kelapa kaya unsur Kalium. Tujuan dari kegiatan pengabdian ini adalah: 1. Meningkatkan pengetahuan para petani tentang pupuk organik cair 2. Meningkatkan keterampilan petani untuk membuat pupuk organik cair dari bahan ekstrak tanaman. Kegiatan pengabdian pada masyarakat ini telah dilaksanakan pada bulan November 2017. Kegiatan pengabdian pada masyarakat ini bertempat di Kelurahan Marga Agung, Kecamatan Jatiagung, Lampung Selatan. Materi yang disampaikan pada kegiatan pengabdian pada masyarakat ini adalah materi pertanian organik yaitu teknik pembuatan pupuk organik cair dari ekstrak tanaman. Pada akhir pengabdian diperoleh bahwa (1) pengetahuan petani sasaran tentang manfaat pemupukan melalui pupuk organik cair telah meningkat 62\%. (2) Tanggapan petani terhadap kegiatan demonstrasi cara pembuatan pupuk organik cair cukup baik dan positif serta petani ingin mencoba membuat sendiri pupuk organik cair untuk dicobakan pada lahan budidaya tanaman pangan petani.
\end{abstract}

Kata Kunci: pertanian organik, penyuluhan, pupuk organik cair, lamtor, batang pisang, sabut kelapa

\begin{abstract}
Organic farming is increasingly popular among farmers as an alternative agricultural practice. The need of major nutrients in organic farming can be provided from natural ingredients that are from plant extract material. Plant organs rich in nutrients such as leaf plant extracts lamtoro rich in Nitrogen, banana stem extract rich in phosphorus and fitohormone and extract coconut fiber rich in potassium. The purpose of this extension activity is 1. Improving knowledge the farmers about liquid organic fertilizer 2. Increase skills farmers to make liquid organic fertilizer from plant extract material. This community service activity was held in November 2017. The community service activity is located in Kelurahan Marga Agung, Jatiagung sub-district, South Lampung. Material presented on extension activities in the community that is an organic farming material namely production technique of a liquid organic fertilizer from plant extracts. At the end of the extension, it was found that (1) knowledge of target farmers about the benefits of fertilization through liquid organic fertilizer has increased $62 \%$. (2) The farmers' perception of the demonstration method activity of liquid organic fertilizer is quite good and positive and the farmers want to try to make their own liquid organic fertilizer to be tested on food-crops farming of farmers
\end{abstract}

Key words: organic farming, extension, liquid organic fertilizer, lantoro, banana stem, coconut fiber

\section{PENDAHULUAN}

1.1 Analisis situasi

Dalam rangka menjalankan otonomi daerah dengan mengutamakan kemandirian pemerintah daerah, perlu ada upaya menggali dan mengoptimalkan berbagai potensi sumberdaya dan keunggulan yang dimiliki suatu wilayah. Desa Marga Agung, Kecamatan Jati Agung merupakan salah satu daerah di wilayah Kabupaten Lampung Selatan yang mempunyai potensi besar untuk pengenbangan pertanian organik. Lokasinya dekat dengan ibukota Provinsi Lampung, Bandar Lampung, dan sebagian besar warganya bermata pencaharian sebagai petani. Saat ini, tanaman sayur mulai dikembangkan di Desa Marga Agung ditandai dengan beberapa kelompok 
tani sudah mulai mengembangkan sistem pertanian sayur organik

Usahatani di Desa Marga Agung selama kurun waktu 10 tahun terakhir masih mengandalkan penggunaan pupuk kimia yang memberikan hasil panen yang tinggi namun ternyata telah menimbulkan dampak terhadap lingkungan. Aplikasi pupuk kimia memang dapat meningkatkan hasil tani, tetapi kenaikan harga pupuk yang sering terjadi akhir-akhir ini telah menurunkan daya beli petani. Di samping itu, penggunaan pupuk secara terus menerus tanpa memperhatikan kaidah-kaidah konservasi tanah dan air dapat mengakibatkan tingkat kesuburan tanah menurun, merusak lahan pertanian, serta mencemari lingkungan hidup. Oleh karena itu saat ini perhatian untuk menggali kembali dan melaksanakan praktek pertanian alternatif semakin besar. Pertanian alternatif yang diandalkan tersebut adalah pertanian organik.

Pertanian organik diartikan sebagai suatu sistem produksi pertanaman yang berazaskan daur ulang hara secara hayati. Daur ulang hara dapat melalui sarana limbah ternak serta limbah tanaman yang mampu memperbaiki status kesuburan tanah (Dermiyati, 2015:15). Pada rpinsipnya, pertanian organik sejalan dengan pengembangan pertanian dengan masukan teknologi rendah (low-input technology) (Sutanto, 2002:24). Handayanto (2017: 182) menjelaskan bahwa salah satu prinsip dasar pengelolaan kesuburan tanah dalam sistem organik adalah bahwa unsur hara tanaman tergantung pada unsur hara yang dihasilkan secara biologis daripada menggunakan unsur hara berbentuk mudha larut atau bentuk unsur hara kurang tersedia seperti bahan organik.

Pemanfaatan bahan organik adalah salah satu teknik penerapan penerapan organik. Dalam kegiatan pengabdian ini bahan organik yang akan digunakan adalah limbah tanaman berupa daun lamtoro, batang pisang, sabut kelapa. Di sekitar lokasi pengabdian melimpah tanaman tanaman yang secara alamiah mengandung unsur Nitrogen seperti misalnya lamtoro atau kacang kacangan. Sutanto (2002:25) menyatakan pertanian organik selalu memanfaatkan bahan lokal setempat atau kearifan tradisional dari masing masing lokasi.

Pupuk organik cair (POC) adalah pupuk organik yang tersedia dalam bentuk cair, di dalamnya terkandung unsur hara berbentuk larutan sehingga sangat mudah diserap tanaman. Pupuk organik cair dapat digunakan dengan cara disiramkan ke tanaman ataupun disemprotkan pada daun atau batang tanaman. Sumber bahan baku pupuk organik cair tersedia dalam bentuk limbah, baik limbah rumah tangga, rumah makan, pasar pertanian, peternakan, maupun limbah organik jenis lain (Nasaruddin dan Rosmawati, 2011:29). Menurut Poerwanto dan Susila (2014:182) bahwa pemberian pupuk cair adalah alternatif pemberian nutrisi tanaman. Untung (2012:13) menjelaskan bahwa aplikasi pupuk berbentuk cair lebih dipilih karena dalam bentuk cair mikroorganisme mampu bertahan hidup hingga tahunan. Oleh sebab itu aplikasi pupuk organik cair ekstrak tanaman sangat dianjurkan dalam budidaya tanaman sebagai asupan unsur hara tanaman.

Pupuk organik cair yang baik adalah bila rasio $\mathrm{C} / \mathrm{N}$ antara $12-15$. Unsur hara yang ada dalam pupuk cair tergantung dari bahan dasar dan cara pembuatannya. Nasaruddin dan Rosmawati (2011:37) melakukan penelitian POC dari hasil fermentasi daun gamal, batang pisang dan sabuk kelapa dengan perbandingan 1:1:1. Hasil penelitian mereka menunjukkan bahwa pemberian pupuk daun organik dari hasil fermentasi daun gamal batang pisang dan sabuk kelapa menghasilkan respon pertumbuhan bibit kakao yang lebih baik. Perlakuan 15 sampai $30 \mathrm{ml} . \mathrm{l}^{-}$ ${ }^{1}$.pohon ${ }^{-1}$ memberikan pengaruh terbaik di banding perlakuan lainnya.

\subsection{Perumusan Masalah}

Masalah utama yang dapat diidentifikasikan dengan jelas di Desa Margo Dadi adalah sumberdaya bahan organik yang ada belum dimanfaatkan secara optimal. Dengan demikian permasalahannya adalah sebagai berikut;

(1) Bagaimana agar petani mempunyai pengetahuan membuat pupuk organik padat.

(2) Bagaimana agar petani mempunyai keterampilan membuat pupuk organik cair

(3) Bagaimana agar petani memahami teknologi penerapan pupuk organik cair sebagi alternatif penggunaan pupuk kimia dalam usahatani sayuran.

\subsection{Tujuan}

Tujuan dari kegiatan pengabdian ini adalah:

(1) Meningkatkan pengetahuan para petani tentang pupuk organik cair

(2) Meningkatkan keterampilan petani tentang pupuk organik cair

(3) Meningkatkan pemahaman petani dalam menerapkan teknologi pemanfaatan pupuk organik cair dalam budidaya tanaman pangan.

\subsection{Manfaat Kegiatan}

Setelah dilaksanakan kegiatan ini, petani akan memperoleh manfaat sebagai berikut:

(1) Petani dapat menekan biaya pembelian pupuk buatan

(2) Petani dapat memanfaatkan limbah, dan daun daun tanaman kaya unsur hara sebagai pupuk organik cair.

(3) Produksi usahatani tanaman pangan akan meningkat sehingga pendapatan petani diharapkan juga akan meningkat. 


\section{METODE KEGIATAN \\ 2.1 Waktu dan Tempat}

Kegiatan pengabdian pada masyarakat ini dilaksanakan dari bulan Juni sampai dengan bulan November 2017. Kegiatan pengabdian pada masyarakat ini bertempat di Kelurahan Marga Agung, Kecamatan Jatiagung, Lampung Selatan.

\subsection{Khalayak sasaran}

Tokoh masyarakat dan petani andalan, pemilik dan penggarap lahan di Desa Marga Agung (Gambar 1) . Petani andalan atau petani maju diharapkan menjadi penggerak atau pelopor. Selain itu juga menjadi contoh dalam mengoptimalkan usaha tani serta memasarkan produk pertanian. Hal ini sangat dimungkinkan karena pengaruh mereka cukup besar.

\subsection{Keterkaitan}

Teknik pembuatan kompos ini didukung oleh tokoh masyarakat, dan juga seluruh aparat desa. Kegiatan ini didukung oleh masyarakat setempat karena petani di Desa Marga Agung akan dapat memanfaatkan aneka jenis tanaman sumber pupuk organik cair yang ada disekitar.

\subsection{Materi Penyuluhan}

Materi yang disampaikan oleh tim penulis dengan melibatkan 2 mahasiswa Fakultas Pertanian Universitas Lampung (Gambar 2) Materi kegiatan pengabdian pada masyarakat ini adalah cara membuat pupuk organik cair dari ekstrak daun lamtoro (Gambar 3), cara membuat pupuk organik cair dari ekstrak bonggol pisang (Gambar 4), dan cara membuat pupuk organik cair dari ekstrak tanaman sabut kelapa (Gambar 5). Materi disampaikan oleh tim pengabdian dosen Fakultas Pertanian Universitas Lampung. Pupuk organik cair dibuat dengan memanfaatkan aneka tanaman lokal yang ada disekitar lokasi.

\subsection{Metode Penyuluhan}

Metode penyuluhan berupa survei awal pendahuluan tentang pengetahuan petani. Dilanjutkan dengan ceramah dan tanya jawab. Kemudian demonstrasi cara pembuatan pupuk organik cair. Pengabdian diakhiri dengan survei akhir tentang pengetahuan petani.

Demonstrasi cara teknik pembuatan pupuk organik cair dilaksanakan sesuai dengan teknik pembuatan pupuk organik cair. Dalam pelaksanaan pembuatan pupuk organik cair melibatkan tenaga lokal setempat. Mahasiswa membantu dalam menjelaskan cara pembuatan pupuk organik cair.

\subsection{Rancangan Evaluasi}

Untuk mengetahui keberhasilan pembinaan petani dalam membuat pupuk organik cair di Desa Marga Agung, Kecamatan Jatiagung dilakukan evaluasi akhir. Evaluasi akhir bertujuan untuk mengetahui manfaat kegiatan pengabdian bagi petani.

\section{HASIL DAN PEMBAHASAN \\ 3.1 Tempat dan Waktu Kegiatan}

Kegiatan penyuluhan telah dilaksanakan di Desa Marga Agung Kecamatan Jatiagung Kabupaten Lampung Selatan.

\subsection{Pelaksanaan Penyuluhan}

Penyuluhan dilaksanakan dengan kegiatan ceramah dan diskusi, kemudian kegiatan demonstrasi cara, dan kegiatan anjangsana dan anjangkarya.

\subsubsection{Kegiatan Cermah Dan Diskusi}

Kegiatan ceramah dilakukan pada hari Senin tanggal 27 November 2017, bertempat di rumah ketua Gabungan Kelompok Tani (Gapoktan) Desa Marga Agung. Ceramah dilakukan pada pukul 19.00 s.d 21.50 WIB. Kegiatan ceramah ini dihadiri oleh petani sebanyak 33 orang anggota kelompok tani (Gambar 1).

Materi yang disampaikan meliputi materi budidaya tanaman palawija secara umum, materi cara pembuatan pupuk organik cair. Selain itu juga diberikan sesuai kebutuhan lokal setempat yaitu cara pemberantasan hama, dan penyakit tanaman, serta dinamika kelompok. Setelah penyampaian materi semua selesai, maka dilanjutkan dengan diskusi dan tanya jawab. Acara dan diskusi dan tanya jawab berlangsung dengan tertib dan menarik, terlihat dari keantusiasan petani untuk lebih memahami tentang pembuatan pupuk organik cair. Banyak pertanyaan yang dilontarkan kepada penceramah, misalnya bahan dasar apa saja untuk membuat pupuk organik cair, bagaimana mengetahui bahwa tanaman kekurangan pupuk $\mathrm{N}$, P, dan $\mathrm{K}$, dan apa penyebab tanaman yang masih muda (masih dipersemaian) busuk pada pangkal batangnya.

\subsubsection{Kegiatan Demontrasi Cara}

Kegiatan demontrasi cara dilakukan setelah dilakukan kegiatan ceramah, diskusi, dan tanya jawab. Materi yang didemontrasikan adalah cara membuat pupuk organik cair dari bahan daun lamtoro, batang pisang dan sabut kelapa. Kegiatan domontrasi ini sangat efektif untuk menyampaikan informasi, karena petani secara langsung dapat melihat dan dapat mempraktikkannya sendiri.

\subsubsection{Kegiatan Anjangsana Dan Anjangkarya}

Kegiatan anjangsana dan anjangkarya dilakukan secara informal kerumah ketua dan anggota Gapoktan. Kegiatan ini berlangsung cukup akrab, dan petani merasa senang sekali dengan adanya kunjungan dari tim penyuluh karena petani dapat kontak secara langsung dan memperdalam materimateri yang telah diceramahkan.

\subsection{Evaluasi Kegiatan}

Evaluasi hasil dilaksanakan setelah pelaksanaan penyuluhan. Tujuannya untuk mengetahui sejauh mana perubahan pengetahuan petani sasaran setelah dilakukan penyuluhan. 
Kegiatan penyuluhan, diskusi dan teknik pembuatan pupuk organik cair mendapat tanggapan yang cukup memuaskan terutama keingintahuan tentang cara-cara membuat pupuk organik cair serta cara menginokulasi mikroorganisme (fermentasi) ke dalam pupuk organik cair. Rata rata peningkatan pengetahuan petani adalah $62 \%$ (Tabel 1). Petani senang dengan adanya penyuluhan ini, karena mereka belum pernah mendapatkan materi tentang teknik pembuatan pupuk organik cair dari bahan ekstrak tanaman.

Tabel 1. Hasil evaluasi tahap awal, tahap akhir dan peningkatan pengetahuan petani tentang pertanyaan aspek aspek pemupukan

\begin{tabular}{|l|l|l|l|}
\hline $\begin{array}{l}\text { Pertanya } \\
\text { an untuk } \\
\text { petani }\end{array}$ & $\begin{array}{l}\text { Tahap } \\
\text { awal }\end{array}$ & $\begin{array}{l}\text { Tahap } \\
\text { akhir }\end{array}$ & $\begin{array}{l}\text { Pening } \\
\text { katan } \\
(\%)\end{array}$ \\
\hline $\begin{array}{l}1 . \quad 4 \text { Jenis } \\
\text { pupuk }\end{array}$ & 40 & 100 & 60 \\
\hline $\begin{array}{l}\text { 2. Manfaat } \\
\text { pemupukan }\end{array}$ & 40 & 100 & 60 \\
\hline $\begin{array}{l}3 \text { Cara } \\
\text { pemupukan }\end{array}$ & 20 & 90 & 70 \\
\hline $\begin{array}{l}4 \quad \text { Pupuk } \\
\text { organik }\end{array}$ & 20 & 80 & 60 \\
\hline $\begin{array}{l}5 \text { Pupuk } \\
\text { organik cair }\end{array}$ & 0 & 80 & 80 \\
\hline $\begin{array}{l}6 \quad \text { Cara } \\
\text { aplikasi } \\
\text { POC }\end{array}$ & 40 & 100 & 50 \\
\hline $\begin{array}{l}7 \quad \text { Manfaat } \\
\text { POC bagi } \\
\text { tanaman }\end{array}$ & 30 & 100 & 60 \\
\hline $\begin{array}{l}8 \text { Teknik } \\
\text { Fermentasi } \\
\text { POC }\end{array}$ & 40 & 100 & 70 \\
\hline $\begin{array}{l}9 \text { Pertanian } \\
\text { organik }\end{array}$ & 50 & 100 & 50 \\
\hline $\begin{array}{l}10 \text { Pencegahan } \\
\text { penyakit } \\
\text { tanaman }\end{array}$ & 40 & 100 & 60 \\
\hline
\end{tabular}

\subsection{Pembahasan}

Hasil kegiatan penyuluhan penerapan teknik pembuatan pupuk organik cair memberikan peningkatan pengetahuan petani. Hal ini berarti bahwa petani cukup memahami materi penyuluhan yang diberikan. Selama diskusi ternyata petani sudah memiliki latar belakang pengetahuan dasar tentang pemupukan sudah cukup dari praktik di lapangan. Hal ini bisa dimengerti karena petani pada umumnya adalah petani yang sudah bekerja di ladang pertanian cukup lama.

Kegiatan demonstrasi cara pembuatan pupuk organik cair yang diadakan oleh tim penyuluh mendapat respon yang positif dari petani. Kegiatan demonstrasi cara pembuatan pupuk organik cair dikerjakan oleh kelompok tani sendiri, mulai dari pengumpulan bahan-bahan sampai dengan pembuatan larutan pupuk organik cair. Kegiatan demikian adalah sesuai dengan prinsip Learning by Doing yaitu belajar dengan cara mempraktikkannya langsung. Selain itu, tim penyuluh juga memberikan pengetahuan langsung kepada petani tentang ciri-ciri pupuk organik cair yang sudah jadi dan matang. Semua petani peserta penyuluh sangat antusias untuk juga membuat pupuk organik cair dengan memanfaatkan sumber daya lokal yang ada.

\section{KESIMPULAN DAN REKOMENDASI \\ 4.1 Kesimpulan}

1) Setelah penyuluhan ternyata pengetahuan petani sasaran tentang manfaat pemupukan melalui pupuk organik cair, telah meningkat $62 \%$

2) Tanggapan petani terhadap kegiatan penyuluhan positif dan antusias.

3) Tanggapan petani terhadap kegiatan demonstrasi cara pembuatan pupuk organik cair cukup baik dan positif serta petani ingin mencoba mempraktikkannya pada usahatani mereka sendiri pada musim tanam selanjutnya.

\subsection{Rekomendasi}

1) Petani diharapkan dapat menyebarkan pengetahuan yang diperoleh kepada petani lain.

2) Perlu Petugas Penyuluh Lapangan (PPL) yang lebih aktif melakukan sosialisasi pertanian organik di Desa Marga Agung, sehingga petani dapat lebih banyak mendapat bimbingan.

\section{UCAPAN TERIMAKASIH}

Pengabdian ini terlaksana melalui dana Hibah BLU Fakultas Pertanian tahun anggaran 2017. Tim mengucapkan terimakasih Gapoktan dan perangkat desa Marga Agung.

\section{DAFTAR PUSTAKA}

Dermiyati. 2015. Sistem Pertanian Organik Berkelanjutan. Penerbit Plantaxia. Yogyakarta.

Handayanto, E., N. Muddarisna, A. Fiqri. 2017. Pengelolaan Kesuburan Tanah. Penerbit UB Press

Nasaruddin dan Rosmawati. 2011. Pengaruh pupuk organik cair (POC) hasil

fermentasi daun gamal, batang pisang dan sabut kelapa terhadap pertumbuhan bibit kakao. Jurnal Agrisistem, 7 (1), 29-37.

Poerwanto, R. dan A. Susila. 2014. Teknologi Hortikultura. Seri Hortikultura Tropika. Penerbit IPB Press.

Sutanto, R. 2002. Pertanian Organik. Penerbit Kanisius. Yogyakarta. 218 hal.

Untung, S. 2012. Mikroba juru masak tanaman. Penerbit Trubus. Jakarta. 


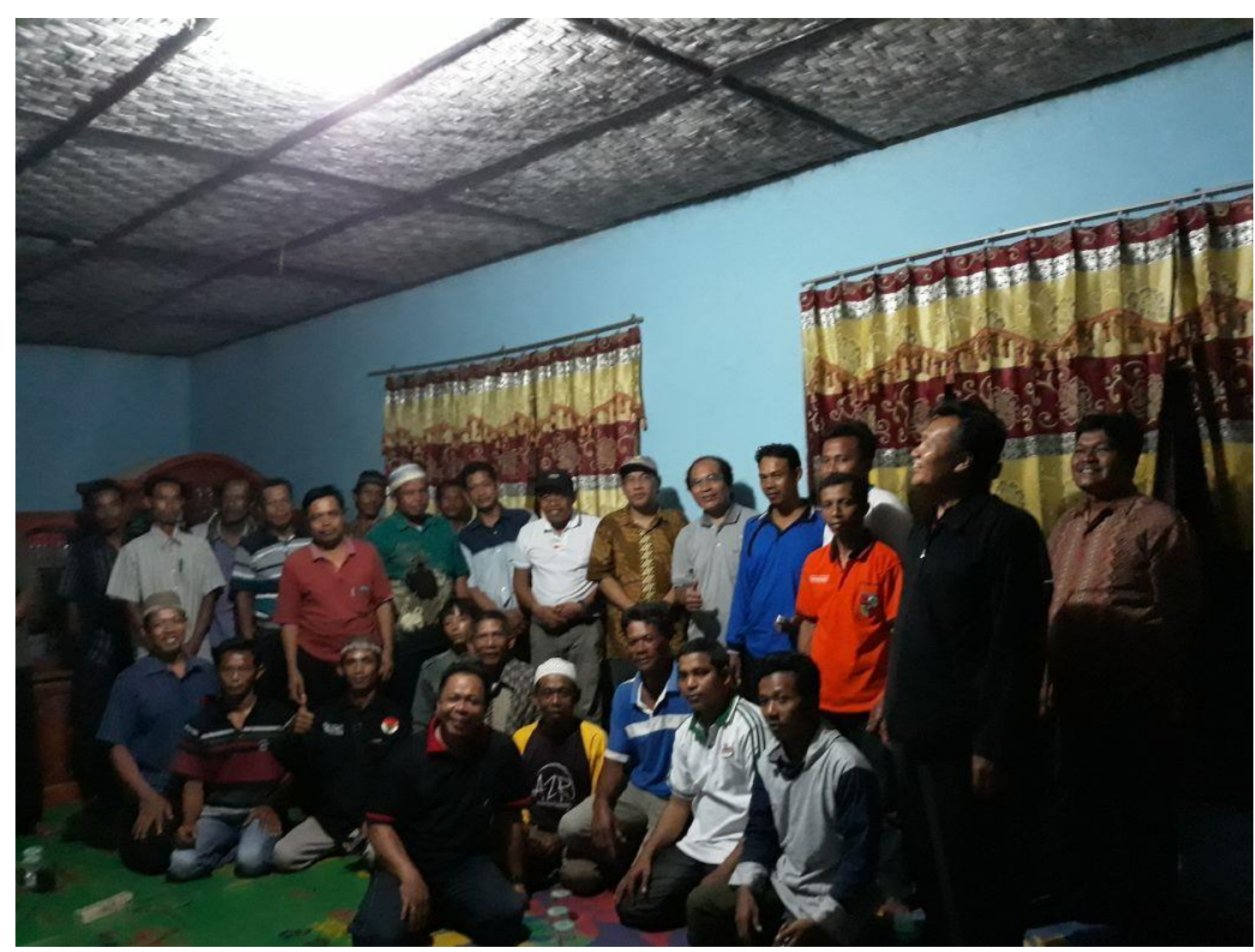

Gambar 1. Foto bersama petani dan tim penyuluh

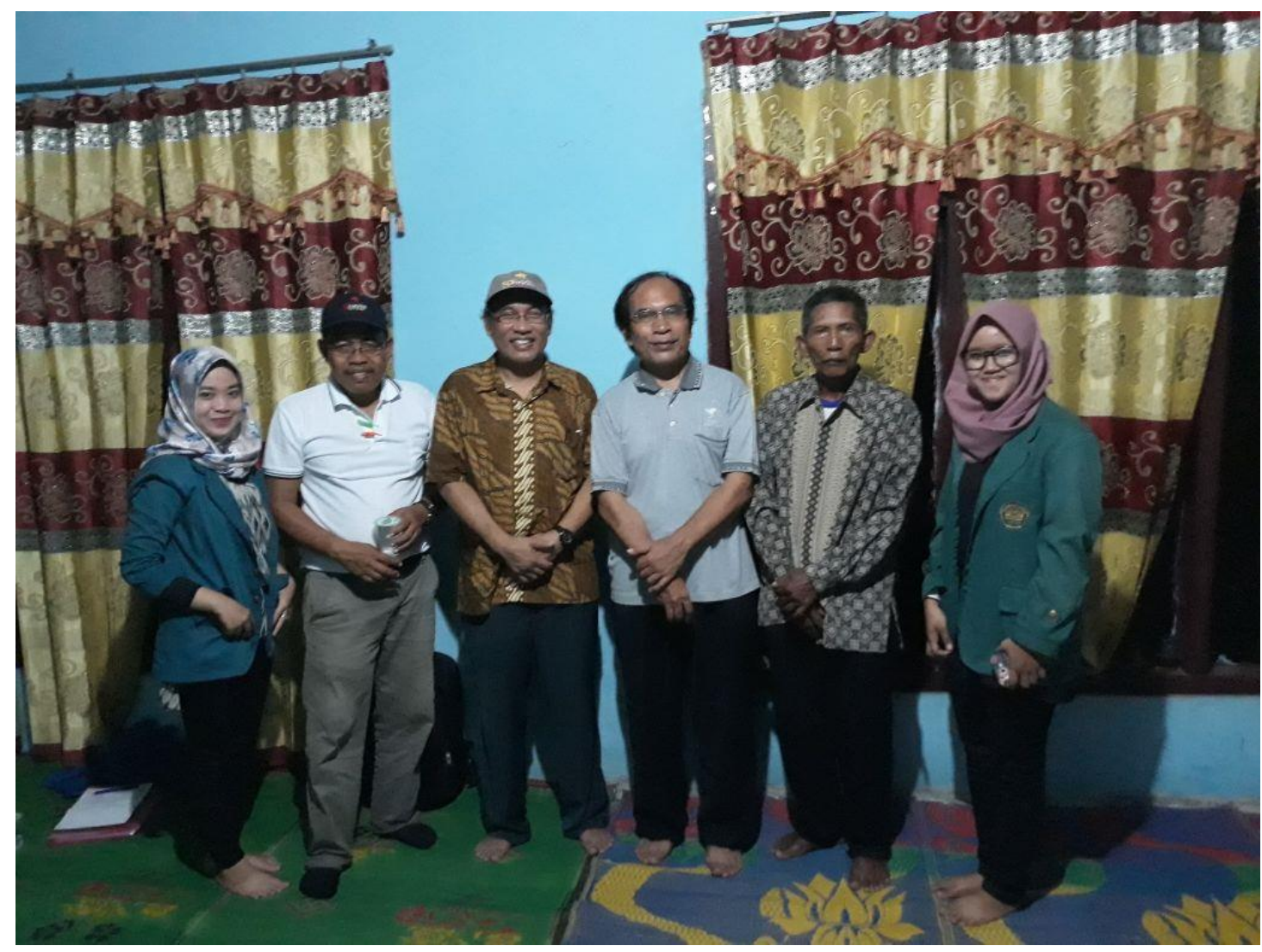

Gambar 2. Tim penyuluh, mahasiswa dan ketua gapoktan 


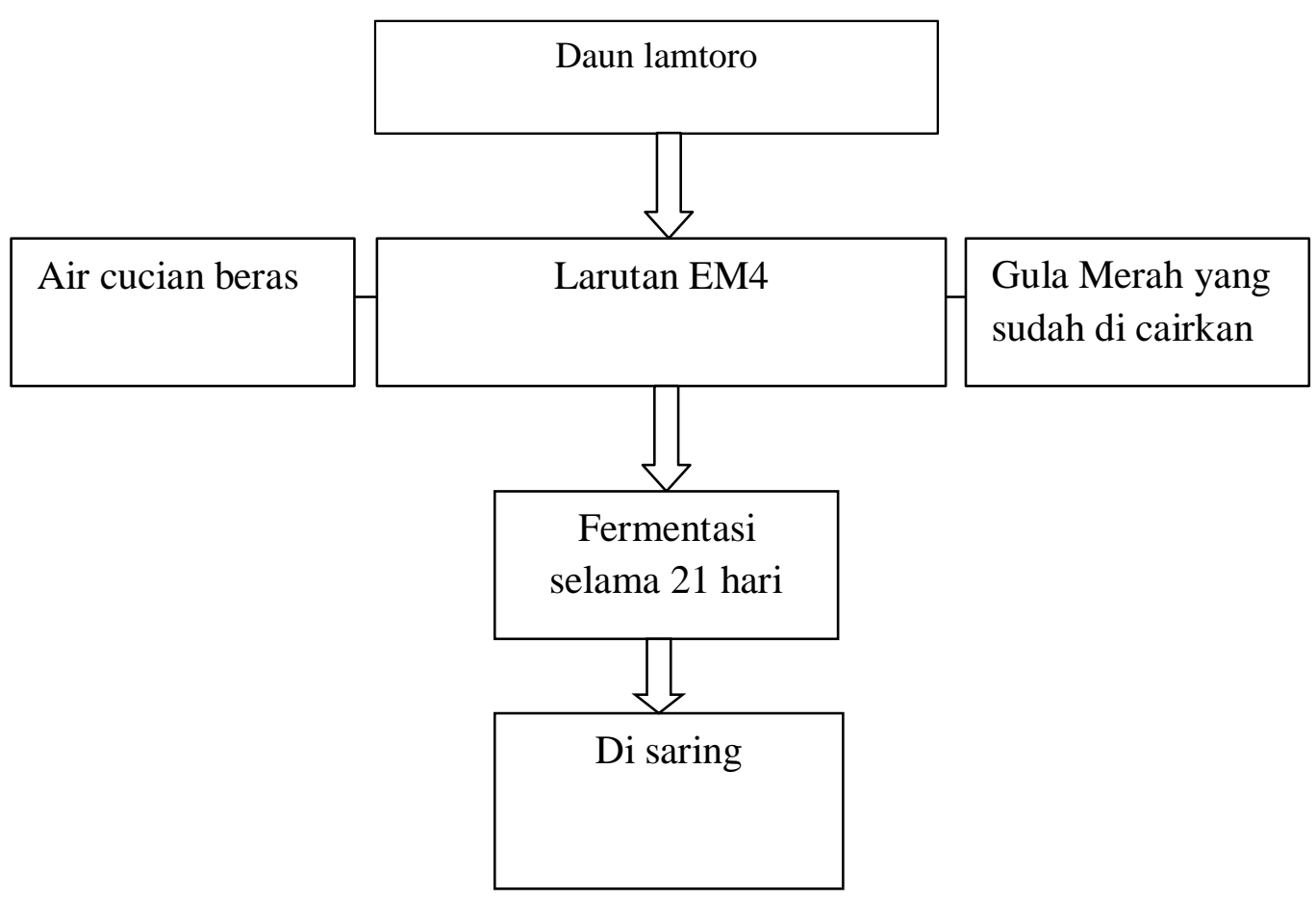

Gambar 3. Skema pembuatan pupuk organik cair ekstrak daun lamtoro.

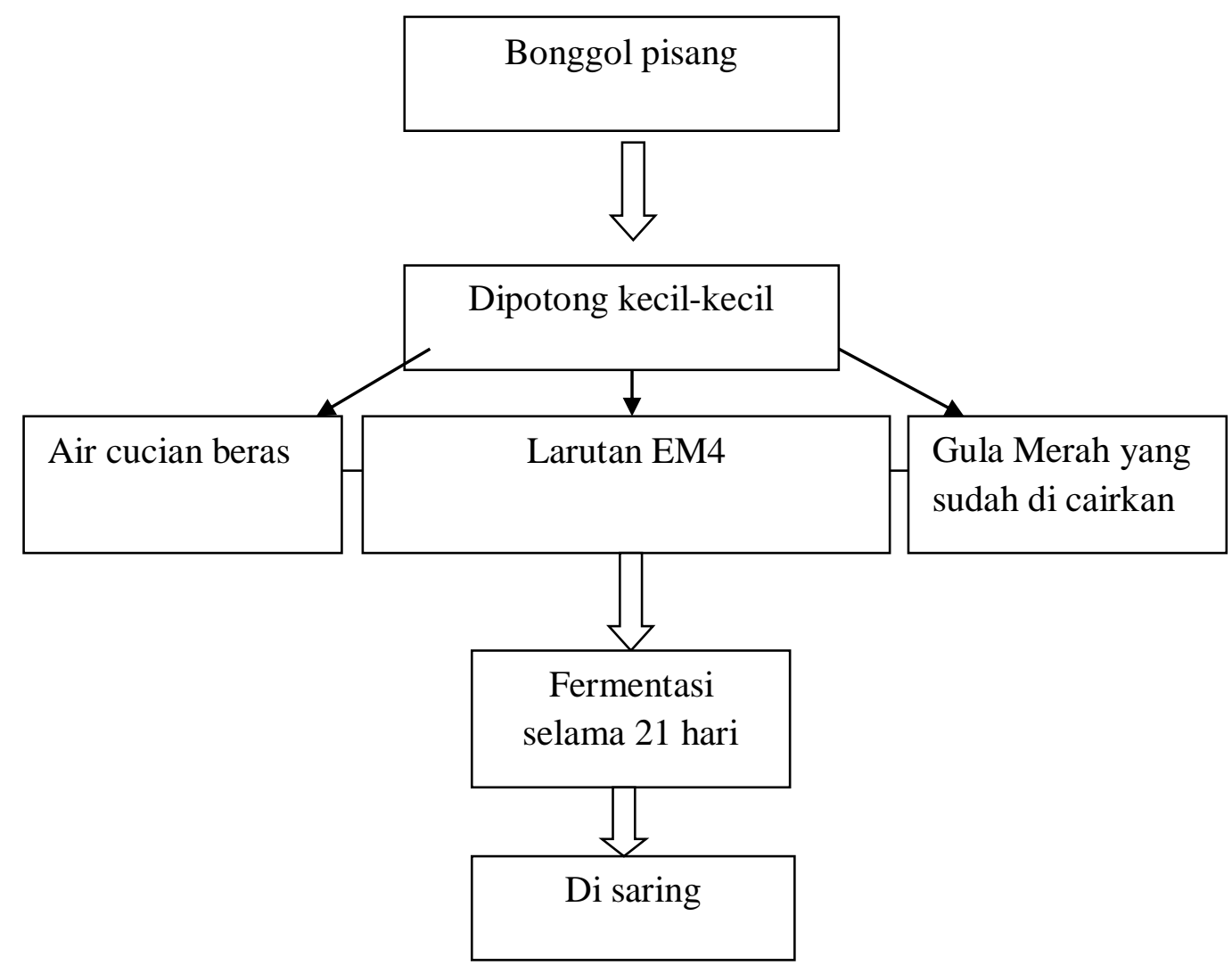

Gambar 4. Skema pembuatan pupuk organik cair ekstrak bonggol pisang. 


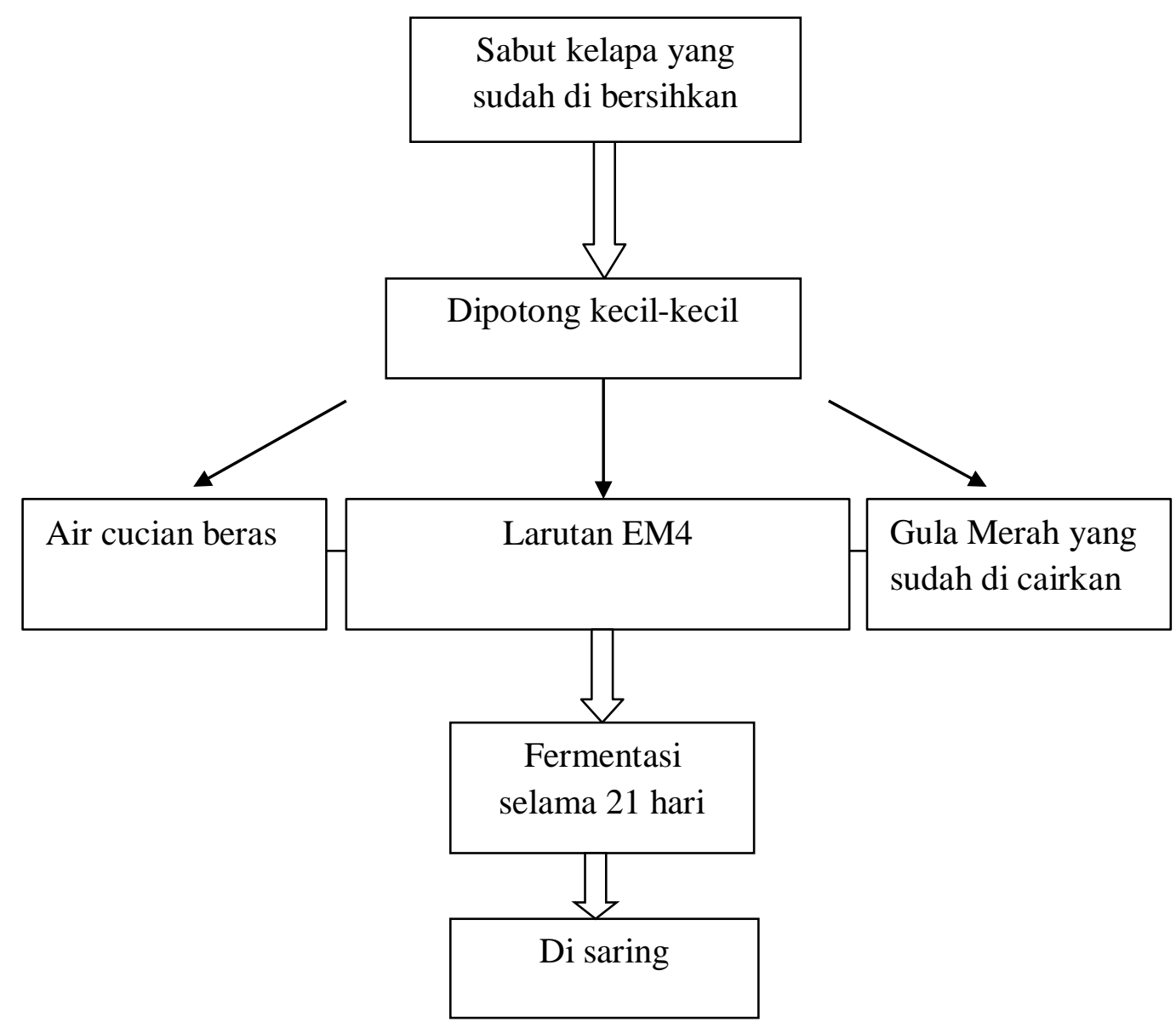

Gambar 5. Skema pembuatan pupuk organik cair ekstrak sabut kelapa. 